\title{
Acoustical Standards Used in Design of School Spaces
}

\author{
D. WRÓBLEWSKA* \\ Gdańsk University of Technology, Narutowicza 11/12, 80-223 Gdańsk, Poland
}

\begin{abstract}
Design guidelines for interior acoustics in learning spaces included in European and American technical standards and other documents are presented. The current Polish regulations referring to interior acoustics are described. The proposal of a set of acoustical guidelines for improving acoustical comfort in school spaces is given.
\end{abstract}

PACS numbers: 43.55.-n, 43.55.+p

\section{Introduction}

So far the room acoustics has not been considered in the design of school rooms. The lack of awareness of the key role that acoustics plays in the quality of learning environment results in poor health of students and teachers as well as it reduces the effectiveness of the educational process and makes it stressful. Both background noise and high reverberance of the room create problems with concentration, speech intelligibility and communication with a teacher. Acoustical discomfort also makes it impossible to rest adequately during breaks when the noise level in recreational spaces such as corridors and halls equals $80 \mathrm{~dB}$ - the level of noise emitted by busy road in the centre of the city. In addition teachers indicate they have to speak at a level that strains their voices and results in throat diseases. Research has proved that good room acoustics reduces the teacher's stress level [1-3]. The problem of poor acoustics increases in rooms for learning and teaching foreign languages and disabled people. A large number of students have undiagnosed hearing problems which make listening and concentrating more difficult in rooms with poor acoustics.

Thus good acoustics should be achieved by the complex approach referring to building, environmental and room acoustics. It should ensure the reduction of:

- environmental noise generated outside the school premises caused mostly by traffic,

- noise transferred by air or building materials from adjacent rooms and outside the school, within the school area, eg. playing fields,

- background noise produced by technical equipment of the building (mainly heating, ventilating, and air conditioning systems).

What is more, the adequate reverberance of the room and reduction of interior background noise level, coming mainly from conversation, whispering, computers, projector machines and furniture, should be considered in order to achieve:

* corresponding author; e-mail: dommi@pg.gda.pl
- good quality of speech communication in spaces such as classrooms, language rooms, sports rooms, computer rooms and other learning spaces,

- high speech intelligibility in spaces such as lecture rooms and auditoriums,

- high quality of sounds in spaces for musical education, concert halls and multifunction rooms for non-amplified music.

The definition of the acoustical parameters as well as their required values is presented in the regulation. As interior acoustics of learning spaces is not regulated by the technical standards, the inspiration may be taken from foreign guidelines and regulations presented below.

\section{Polish standards}

The Polish regulations refer only to the issues of environmental and building acoustics. The maximum value of the external noise coming from traffic and other sources at the school premises should not exceed the level of $55 \mathrm{~dB}(\mathrm{~A})$ during daytime [4] (most city schools situated by the busy roads are exposed to noise at the level of 70-90 dB(A)).

The building acoustics standards also define required values of airborne and impact sound isolation of walls and ceilings to protect against external and internal noise according to PN-B-02151-3:1999 [5]. The required minimum values of $R_{\mathrm{A} 1}^{\prime}$ for airborne sound isolation vary from $50 \mathrm{~dB}$ for ceiling and $40-50 \mathrm{~dB}$ for walls depending on the function of a nearby room. Considering the impact sound isolation, the required maximum levels of $L_{n, w}^{\prime}$ for ceiling vary from $53-63 \mathrm{~dB}$, with the individual declared values for ceiling between the protected room and sanitary rooms and halls.

According to PN-87/B-02151/02 [6] the accepted noise level in the learning spaces room created by all external and internal sound sources (coming from technical equipment and from nearby/adjacent rooms) should be not higher than $40 \mathrm{~dB}(\mathrm{~A})$ and from technical equipment $35 \mathrm{~dB}(\mathrm{~A})$, and in teachers' room respectively 35 and $30 \mathrm{~dB}(\mathrm{~A})$. 
Additionally, the requirements to ensure protection for employees against health hazards related to the exposure to noise regulated by the ordinance of the Minister of Labour and Social Policy [7] on general principles of safety and hygiene at work must be applied. PN-N-01307: 1994 [8] indicates that the acceptable equivalent level of noise within the time spent by an employee at a workplace should not exceed the levels of $55 \mathrm{~dB}(\mathrm{~A})-$ in administrative units, office and conceptual work rooms and $65 \mathrm{~dB}(\mathrm{~A})$ in secretary's offices and customer service offices.

The latest amendment to technical requirements adds a new component - the reverberation noise to the general regulation on mitigation and control of noise pollution [9]. This noise results from reflection of sound from building barriers surrounding the interior space. The new regulation also requires the obligatory usage of acoustically tested finish materials in interiors devoted to reception of speech or other acoustical signals. What is more, further Polish technical standards referring to building acoustics are added. Unfortunately, currently Poland lacks standards of acoustical designing interiors in order to abatement of reverberation noise and increase of quality of sound. The process of standards' elaboration is being still continued. Meanwhile the requirements and methods described in foreign guidelines and standards or literature can be used.

To make the building process complete, the control of design and realization quality should be conducted. Nowadays, the regulations which can help verify the project or control the building process with regard to the noise protection issues makes the law dead. Designed materials are often changed into the other ones without the verification of their acoustical properties or not laboratory tested materials or equipment systems are used. In the new Building Law a paragraph introducing the Acoustical Characteristics of a Building - the new obligatory attachment to a building design documentary (included in the project dated from March, 2008) was rejected. The information was to consist of declared parameters and their designed values for protection against external noise and the one caused by technical equipment.

\section{Foreign standards}

The European, American and New Zealand's regulations on architectural acoustics standards of public service buildings (including schools) were revised. The main purpose of regulations is to decrease the noise and to ensure the proper acoustical conditions for good communication, speech intelligibility and the sound of music. Two documents SFS 5907:2004 [10] and NS 8175:2005 [11] distinguish the acoustical classes of building depending on the recommended values. Most standards do not apply to special-purpose classrooms, rooms of a large volume or rooms of unique or more stringent acoustical requirements such as large auditoria and concert halls, the designing of which should be consulted with acousti- cians. Rooms for education of students with hearing impairment or language classrooms should have the acoustical requirements concerning reverberation stricter by about $20 \%$.

The requirements are based on optimal values of different acoustical parameters such as: sound absorption coefficient $\alpha$, reverberation time (RT), sound to noise ratio (SNR) and speech transmission index (STI).

Coefficient $\alpha$ is a measure of the ability of a material to absorb sound and equals the ratio of the intensity of the absorbed sound to the intensity of the incident sound. It ranges from about 0.05 to about 1.0 for highly sound-absorbing materials. ÖNORM B 8115-3 [12] assumes the control of interior noise level by defining the minimal value of the average absorption coeficient $\alpha_{m}$ of the room in the range of $125-4000 \mathrm{~Hz}$. For the sparsely furnished rooms such as corridors, gymnastic halls, swimming pools $\alpha=0.23$ and for fully furnished such as working and administration rooms $\alpha=0.29$.

SNR is controlled by two factors, the signal level of the teacher's voice at the student's ear and the background noise. Research [13] has proved that in classrooms having a signal-to-noise ratio of less than $+10 \mathrm{~dB}$, speech intelligibility is significantly degraded for children with average hearing. Since an adult voice is designed for a normal speech volume of around 50 to $55 \mathrm{~dB}(\mathrm{~A})$, this means that the noise interference level must be less than $40 \mathrm{~dB}(\mathrm{~A})$ [2]. The demanded values of SNR are included for example in ANSI S12.60-2002 [14].

STI describes the degree of speech intelligibility in the room. The reference values of good speech intelligibility is when STI $>0.6$ and the very good when STI $>0.75$. For classrooms, speech intelligibility can be predicted from reverberation time and signal-to-noise ratio. A classroom with a 0.5 second RT and $+10 \mathrm{~dB} \mathrm{~S} / \mathrm{N}$ will have approximately 90 percent speech intelligibility. If the RT is kept at 0.5 seconds but the $\mathrm{S} / \mathrm{N}$ is reduced to $0 \mathrm{~dB}$, intelligibility falls to about 55 percent [13]. The parameter is used as a standard in BB93 [15] guidelines and its minimal value of 0.6 is given for indoor rooms designed as open-space. The SFS 5907:2004 standards define STI for classrooms depending on its acoustical class. STI should be equal or more than 0.80 in class A, B and adequately 0.70 for $\mathrm{C}$ class. For students with hearing impairment the values are lower between 0.85 and 0.75

$\mathrm{RT}$ is a measure of the amount of reverberation in the space and equals the time required for the level of the steady sound to decay by $60 \mathrm{~dB}$ after it has been turned off. The decay rate depends on the amount of sound absorption in a room, the room geometry, and the frequency of the sound. For high quality of speech RT should not exceed $0.6 \mathrm{~s}$ and for good music should be higher 1-2.5 s depending on the sort of music. In multi-purpose rooms, $\mathrm{RT}$ is a compromise and its values equal $1 \mathrm{~s} \pm 10 \%$. The influence of RT on hearing is presented in Table I.

All standards include recommended values of RT (s). The maximum average values of RT are given for the different ranges of frequency as following: 500-2000 Hz 
TABLE I

The average speech intelligibility by children of monosyllabic words for given RT (s) [16].

\begin{tabular}{c|c|c}
\hline \hline RT (s) & Normal hearing & $\begin{array}{c}\text { Children with } \\
\text { hearing impairment }\end{array}$ \\
\hline 0.0 & $94.5 \%$ & $87.5 \%$ \\
0.4 & $82.8 \%$ & $69.0 \%$ \\
1.2 & $76.7 \%$ & $61.8 \%$
\end{tabular}

(ANSI, BB93); 125-4000 (ÖNORM B 8115-3); 250-4000 NS 8175:2005, SS 25268:2001[17], SFS 5907:2004 and 100-5000 SN 520181 [18]. The recommended values for different rooms are directly given or defined as a function of room volume. Except BB93 RT concerns the fully furnished and unoccupied rooms. For occupied spaces the reverberation times are expected to be $0.1 \mathrm{~s}$ to $0.2 \mathrm{~s}$ less than given for rooms of a small or medium size. If given, design guidelines for controlling reverberation are based on the calculation of the total room absorption due to the floor surface (ANSI S12.60-2002).

For example the recommended RT for an unoccupied and furnished classroom (the floor surface about $80 \mathrm{~m}^{2}$ and height of $3 \mathrm{~m}$ what gives the value of $240 \mathrm{~m}^{3}$ ) varies from 0.4 (New Zealand) [19], 0.5 (the best acoustical class) to $0.8[10,11]$ and the value of $R T=0.6$ (defined or calculated) in the other standards. For the sports hall of the value $V=5600 \mathrm{~m}^{3}$ the recommended values vary form 1.5 in accordance with BB93, 1.82 in accordance with DIN 18041:2004 [20] up to 2.27 in accordance with SN 520181.

\section{Set of general rules}

All standards applying to architectural acoustics slightly differ. Thus the set of acoustical guidelines require the discussion while adapting them to Polish school architectural standards for the different sorts of schools. The guidelines should fit the modern teaching methods concentrating rather on students than teachers (group projects, free classroom arrangements, multi-action spaces).

For young students from primary and junior high schools, the division of school spaces according to their main acoustical requirements is presented in Table II.

\section{TABLE II}

The division of school spaces according to their main acoustical requirements (function and parameter).

\begin{tabular}{l|l|l}
\hline \hline \multicolumn{1}{c|}{ Room } & \multicolumn{1}{c}{$\begin{array}{c}\text { Acoustical } \\
\text { requirements }\end{array}$} & \multicolumn{1}{c}{$\begin{array}{c}\text { Suggested acoustical } \\
\text { parameter }\end{array}$} \\
\hline $\begin{array}{l}\text { workshop rooms, libraries, dining rooms, office } \\
\text { rooms for administration, therapy rooms (speech } \\
\text { therapists, educators, psychologists), computer } \\
\text { rooms, sports halls and swimming pools. }\end{array}$ & basic communication, & $\mathrm{RT}$ \\
\hline corridors and staircases & basic communication & $\begin{array}{l}\text { amount of required absorption: } \\
\text { total room absorption or sound } \\
\text { absorption coefficient }\end{array}$ \\
\hline $\begin{array}{l}\text { lecture rooms, open spaces, classrooms } \\
\text { classrooms primarily for unamplified music class, } \\
\text { instrument and vocal exercises }\end{array}$ & $\begin{array}{l}\text { high speech intelligi- } \\
\text { bility }\end{array}$ & RT \\
\hline $\begin{array}{l}\text { multi-purpose halls and rooms for school perfor- } \\
\text { mance suitable for a variety of activities with un- } \\
\text { amplified music and speech }\end{array}$ & $\begin{array}{l}\text { high quality of music } \\
\text { sound high speech in- } \\
\text { telligibility }\end{array}$ & RT \\
\hline $\begin{array}{l}\text { multimedia rooms } \\
\text { Righ amplified sound } \\
\text { intelligibility }\end{array}$ & $\begin{array}{l}\text { amount of required absorption: } \\
\text { total room absorption or sound } \\
\text { absorption coefficient }\end{array}$
\end{tabular}

The set of additional general rules presented below may be considered as the introduction to discussion on acoustical rules for good acoustics design in school rooms.

- The acoustics of rooms for speech, music and multi-purpose room should be supported with additional design guidelines (graphical and written) presenting the geometry, the way of absorbing and reflecting finishing materials application.
- For the volume of the room exceeding 1500-2000 $\mathrm{m}^{3}$, the design of the above-mentioned should be consulted with acousticians.

- Recommendations for architectural acoustics should be defined for fully furnished rooms and unoccupied for all the rooms, except these for listening music, where lowering RT by full occupancy can interfere the quality of the music sound. 
- For foreign language classes and disabled students the requirements referring to reverberance should be stricter by about $20 \%$.

- The maximum values of RT should depend on the room volume. For rooms below $600 \mathrm{~m}^{3}$ for speech communication RT of $0.6 \mathrm{~s}$, will not degrade speech intelligibility excessively as long as signal-to-noise ratio of minimum $+15 \mathrm{~dB}$ is maintained. This means that at the same time the background noise level should be $35 \mathrm{~dB}(\mathrm{~A})$ or less in an unoccupied room. For rooms above $600 \mathrm{~m}^{3}$ values of RT should be defined by the function of the room volume. Managing noise level at $35 \mathrm{~dB}(\mathrm{~A})$ can make the task of mechanical engineering and contracting very difficult and costly, thus the lower values of RT are recommended.

- The usage of parameters requiring professional testing and designing should be limited to the rooms designed by acousticians. For example, STI is the parameter that should be verified only by special acoustical measurements.

- Acoustical parameters should be achieved and controlled by methods based on a quick and easy calculation, especially for rooms of small volume. The example of the easy procedure of estimating the amount of sound-absorbing materials for recommended reverberation time, based on calculation of the minimum surface area of acoustical treatment for different sound absorption coefficients, ceiling heights, and reverberation times is given by ANSI S12.60-2002.

\section{Summing up}

While designing a school or planning its renovation it is important to realize that good acoustics has a great impact on students and teachers. A lot of acoustical goals can be achieved by the properly designed school layout and surroundings or the usage of acoustically verified materials and building constructions. All regulations referring to environmental and building acoustics applying to the reduction of outdoor and indoor noise should be met and monitored during the investment process. The acoustical requirements should be included in the project or renovation of the building put out to tender. The requirements for room acoustics should be defined and introduced as quickly as possible as a set of directives or regulations to allow for the adoption of the complex approach in school design.

\section{Acknowledgments}

The author would like to thank an architect Mikołaj Jarosz for providing access to European regulations.

\section{References}

[1] B.M. Shield, J.E. Dockrel, J. Acoust. Soc. Amer. 123/1, (2008).

[2] M. Oberdörster, G. Tiesler, Modern school acoustics. A complement to the book Don't limit your senses, Sound and the Learning Environment, Saint-Gobain Ecophon, (2002).

[3] J.E. Dockrell, B.M. Shield, British Educational Research Journal 32, 509 (2006).

[4] Regulation of Minister of Environment. Act of June 6th 2007 on Permissible Sound Levels in the Environment. Journal of Law No 120.2007 , item 826, (in Polish).

[5] Polish Norm PN-B-02151-3:1999.

[6] Polish Norm PN-87/B-02151/02.

[7] Regulation of Minister of Labor and Social Policy. Act of October 26th 1997 on General Regulations of Health and Safety at work. Journal of Law No 169/2003, item 1650, (in Polish).

[8] Polish Norm PN-N-01307:1994.

[9] Regulation of Minister of Infrastructure. Act of March 12th 2009 changing act on technical specification buildings and their location should correspond with . Journal of Law No 56/2009, item 461, (in Polish).

[10] SFS 5907:2004 Rakennusten akustinen luokitus. (Acoustic classification of space in buildings — Finland).

[11] NS 8175:2005 Lydforhold $i$ bygninger. Lydklasser for ulike bygningstyper (Acoustic condition in buildings. Sound quality classification of various types of buildings - Norway).

[12] ÖNORM B 8115-3 Schalschutz und Raumakustik im Hochbau. Teil 3: Raumakustik. 2005 (Germany).

[13] Classroom acoustics - a resource for creating learning environments with desirable listening conditions. The Technical Committee on Architectural Acoustics of the Acoustical Society of America, (2000).

[14] American National Standards Institute. ANSI S12.60-2002: Acoustical performance criteria, design requirements, and guidelines for schools, New York 2002.

[15] Building Bulletin 93. Acoustic Design of Schools. Part E4 of Building Regulations 2000, United Kingdom (2003).

[16] E.A. Wetherill Classroom Design for Good Hearing. The Quiet Zone. Noise PollutionClearinghouse www .nonoise.org (2002).

[17] SS 25268:2001 Byggakustik - Ljudklassning av utrymmen $i$ byggnader - Vardlokater, undervisningslokater, dag - och fritidshem, kontor och hotels (Acoustics - Sound classification of spaces in buildings - public service buildings - Sweden).

[18] SN 520181 Schalschutz im Hochbau, (2009). (Switzerland).

[19] BRANZ LTD. Acoustics Guide. Ministry of Education, New Zealand, (2007).

[20] DIN 18041:2004 Horsamkeit in kleinen bis mittelgrossen Raumen. (Germany). 